\title{
CATÁLOGO DE LOS ESPECÍMENES TIPO DE CRINOIDEOS (ECHINODERMATA: CRINOIDEA) DEL ARCHIPIÉLAGO CUBANO
}

\author{
Daniel Delgado Hofmann, Alina Blanco, Elida Lemus, Elena Gutiérrez, María V. Orozco, \\ Yusimí Alfonso, Rolando Cortés e Isis L. Álvarez
}

Departamento de Biodiversidad Marina, Acuario Nacional de Cuba, Ave. Primera y Calle 60, Miramar, Playa, La Habana, CP 11300, Cuba. danield@acuarionacional.cu

\begin{abstract}
RESUMEN
Se ofrece un listado de los 13 especímenes tipo de crinoideos cubanos (Clase Crinoidea) con sus datos taxonómicos, extraídos de las bases de datos de las instituciones que los atesoran. Los resultados han sido ordenados en forma de catálogo, con la sistemática más actualizada de las especies, la institución donde se encuentra depositado el ejemplar y su respectivo número catalográfico, la localidad tipo y la referencia bibliográfica. Para algunas especies se incluye además la fecha de colecta, la expedición donde se colectaron los ejemplares, la profundidad de colecta y en ocasiones el nombre del colector. La información ofrecida hasta el presente se encontraba dispersa por lo que esta recopilación constituye un aporte valioso y práctico para futuras consultas y estudios taxonómicos.
\end{abstract}

Palabras clave: Echinodermata, Crinoidea, Cuba, plumas de mar, tipos.

Title: Catalog of type specimens of the cuban archipelago crinoids (Echinodermata: Crinoidea).

\section{ABSTRACT}

An updated list of the 13 type specimens of crinoids (Crinoidae) from the Cuban Archipelago is presented. Data was obtained from the depositary institution's. Results are presented as a catalog with the updated systematic, depositary institution, catalog number, type locality and bibliographic reference. When possible we also included the collecting date, expedition name, depth and collector name. All this data was previously dispersed until now making the present summary a valuable and accessible contribution for further taxonomic studies.

Keywords: Echinodermata, Crinoidea, Cuba, feather stars, type.

\section{INTRODUCCIÓN}

Los crinoideos constituyen el único grupo sésil dentro del Phylum Echinodermata. Son organismos pedunculados que se pueden encontrar principalmente en los arrecifes coralinos. La mayoría de las especies de este grupo viven desde los $100 \mathrm{~m}$ hasta los $1000 \mathrm{~m}$, aunque se pueden encontrar hasta los $9000 \mathrm{~m}$ de profundidad (Rodríguez-Barreras y Messing, 2013). Los crinoideos existentes en la actualidad se encuentran divididos en cuatro grandes órdenes: Isocrinida, Hyocrinida, Cyrtocrinida y Comatulida. Sin embargo, recientes investigaciones (Hemery et al., 2013; Rouse et al., 2013) han llevado a la mayoría de los miembros a formar un quinto Orden: Bourgueticrinina.

Los primeros crinoideos conocidos en aguas cubanas fueron descritos e ilustrados por Parra (1787), quien los llamó vulgarmente como "palma animal". Casi un siglo después, Pourtalès (1868) describió los primeros comatúlidos que habitaban en las aguas cubanas, los cuales 
pertenecían al género Antedon (actualmente Crinometra), que fueron colectados durante el primer dragado en aguas profundas en el Atlántico centro-occidental. Paralelamente se realizaron otras expediciones científicas en el buque "Albatros" (entre 1884 y 1885) de las cuales derivaron importantes publicaciones sobre estos organismos marinos (Agassiz,1888; H. L. Clark, 1900 y 1933; A. H. Clark, 1931).

En décadas posteriores se publicaron varios catálogos sobre los equinodermos cubanos, en los cuales se incluían a los crinoideos (Suárez, 1974; Abreu, 1990, 1997; Abreu et al., 2000). En otros catálogos publicados en el presente siglo por Abreu et al. (2005) y del Valle et al. (2005), solo el último menciona a las especies de crinoideos de aguas poco profundas.

Los crinoideos de las aguas cubanas son un grupo que continúa bajo estudio y la ecología, crecimiento, alimentación y distribución de los isocrínidos han sido temas de investigación en áreas adyacentes a Cuba, (Messing y Dearborn, 1990; Messing, 2003 y 2004; Baumiller y Messing, 2007; Messing et al., 2007; Baumiller et al., 2008).

Con los avances de las tecnologías informáticas y la creación de la web, ha sido posible digitalizar y poner a disposición de la ciencia muchos documentos y bases de datos. Sin embargo, en la actualidad hay países donde estas tecnologías no están totalmente disponibles, por ello es necesario la creación de nuevos catálogos, y otros productos informáticos como multimedias (Ibarzábal Bombalier et al., 2010) y páginas web, que puedan llevar la información a más usuarios que la necesitan. Por ello, el Acuario Nacional de Cuba realizó una investigación con la finalidad de elaborar un nuevo catálogo de las especies tipo de los órdenes Isocrinida y Comatulida.

\section{OBJETIVO}

- Resumir las especies tipo de crinoideos cubanos en una lista actualizada y debidamente referenciada, que sirva de base a futuras investigaciones taxonómicas, ecológicas y zoogeográficas.

\section{MATERIALES Y MÉTODOS}

El material utilizado para confeccionar el catálogo fue tomado del Proyecto "Multimedia Tipos Marinos Cubanos". Para su publicación en grupos zoológicos individuales se utilizaron los datos extraídos de la literatura original donde se encuentran sus descripciones como especímenes tipo.

Los datos acompañantes que se han tenido en cuenta son: clase, orden, familia y especie; autor y año de descripción. Además se agregan, la institución donde se encuentra depositado el holotipo y/o los paratipos y su número catalográfico, la localidad tipo, la fecha de colecta, (en el caso que la posea), la profundidad y la expedición en que se realizó la colecta.

\section{RESULTADOS}

Catálogo de los especímenes tipo de crinoideos cubanos.

Clase Crinoidea

Orden Isocrinida

Familia Isselicrinidae 
Endoxocrinus (Endoxocrinus) parrae prionodes (H. L. Clark, 1941)

Holotipo: MCZ 1000.

Institución depositaria: Museo de Zoología Comparada de la Universidad de Harvard, EE.UU. Localidad: St. 3438, frente a Caibarién, costa norte de la provincia de Santa Clara, Cuba.

Profundidad: 265 brazas

Referencia: Reports on the scientific results of the Atlantis Expeditions to the West Indies, under the joint auspices of the university of Havana and Harvard University. The Echinoderms (Other than Holothurians). Memorias de la Sociedad Cubana de Historia Natural "Felipe Poey," vol. XV, no. 1: 6-7.

Endoxocrinus (Endoxocrinus) parrae (Gervais, 1835)

Holotipo: desconocido.

Institución depositaria: desconocida.

Localidad: Cuba.

Profundidad: 84-1095 brazas.

Referencia: Encrines, in Guérin, Dictionnaire pittoresque d'histoire naturelle et des phénomènes de la nature. Lenormand (éd.), Paris 3: 48-49.

Orden Comatulida

Familia Comasteridae

Neocomatella alata (Pourtalès, 1878)

Holotipo: USNM 34482.

Institución depositaria: Museo Nacional Smithsoniano, Washington, D. C., EE.UU.

Localidad: Station 2321, frente a la Habana, Cuba.

Profundidad: 230 brazas.

Referencia: Crinoids. Report on the results of dredging, under the supervision of Alexander Agassiz in the Gulf of Mexico by the United States Coast Survey steamer "Blake”. Bulletin of the Museum of Comparative Zoology at Harvard College, 5 (9): 214-216.

Trichometra cubensis (Pourtalès, 1869)

Holotipo: desconocido.

Institución depositaria: desconocida.

Localidad: desconocida.

Profundidad: desconocida. 
Referencia: List of the Crinoids obtained on the Coasts of Florida and Cuba, by the US Coast Survey Gulf Stream Expeditions, in 1867, 1868, 1869. by L. F. de Pourtalés, Assist U S Coast Survey. Bulletin of the Museum of Comparative Zoology at Harvard College, 1 (11): 356.

Familia Charitrometridae

Crinometra brevipinna (Pourtalès, 1868)

Holotipo: USNM 25473.

Institución depositaria: Museo Nacional Smithsoniano, Washington, D. C., EE.UU.

Localidad: Stations Nos. 2319-2350, frente a la Habana, Cuba.

Profundidad: 279 brazas.

Referencia: Descriptions of seventeen new species of recent crinoids. Proceedings of the United State National Museum, 36: 644-645.

Familia Antedonidae

Coccometra guttata (H. L. Clark, 1918)

Holotipo: USNM 22675.

Institución depositaria: Museo Nacional Smithsoniano, Washington, D. C., EE.UU.

Localidad: St. 2134 frente a la costa SE de Cuba.

Profundidad: 455 metros.

Referencia: The unstalked crinoids of the Siboga expedition. With XXVIII plates and 17 text figures. Siboga Expedition XLII b: 219-220.

Caryometra alope (H. L. Clark, 1940)

Holotipo: MCZ 1010.

Institución depositaria: Museo de Zoología Comparada de la Universidad de Harvard, EE.UU. Localidad: At. 2989, Canal de San Nicolás, costa norte de la provincia de Santa Clara.

Profundidad: 360 brazas.

Referencia: The family Antedonidae in the West Tropical Atlantic.

Memorias de la Sociedad Cubana de Historia Natural, 14 (2): 156.

Caryometra atlantidis (H. L. Clark, 1940)

Holotipo: MCZ 1011.

Institución depositaria: Museo de Zoología Comparada de la Universidad de Harvard, EE.UU. Localidad: St. 3394, Canal Viejo de Bahamas, frente a Camagüey. 
Profundidad: 200 brazas.

Referencia: The family Antedonidae in the West Tropical Atlantic.

Memorias de la Sociedad Cubana de Historia Natural, 14 (2): 148.

Caryometra lisa (H. L. Clark, 1940)

Holotipo: MCZ 1012.

Institución depositaria: Museo de Zoología Comparada de la Universidad de Harvard, EE.UU.

Localidad: St. 2990, frente a Puerto Sagua La Grande, Canal de San Nicolás, provincia de

Santa Clara.

Profundidad: 390 brazas.

Referencia: The family Antedonidae in the West Tropical Atlantic.

Memorias de la Sociedad Cubana de Historia Natural, 14 (2): 154.

Caryometra monilicirra (H. L. Clark, 1940)

Holotipo: MCZ 1013.

Institución depositaria: Museo de Zoología Comparada de la Universidad de Harvard, EE.UU.

Localidad: desconocida.

Profundidad: desconocida.

Referencia: The family Antedonidae in the West Tropical Atlantic.

Memorias de la Sociedad Cubana de Historia Natural, 14 (2): 144.

Caryometra spinosa (H. L. Clark, 1940)

Holotipo: MCZ 1014.

Institución depositaria: Museo de Zoología Comparada de la Universidad de Harvard, EE.UU.

Localidad: St. 3320.

Profundidad: no especificada.

Referencia: The family Antedonidae in the West Tropical Atlantic.

Memorias de la Sociedad Cubana de Historia Natural, 14 (2): 151.

Caryometra tenuipes (Clark, 1937)

Holotipo: USNM 22677.

Institución depositaria: Museo Nacional Smithsoniano, Washington, D. C., EE.UU.

Localidad: Estación No. 2348; frente a la Habana, Cuba.

Profundidad: 211 brazas. 
Referencia: Five new genera and two new species of unstalked crinoids. Proceedings of the United States National Museum, 83 (2982): 245-250.

Familia Atelecrinidae

Atelecrinus pourtalesi (H. L. Clark, 1908)

Holotipo: desconocido.

Institución depositaria: desconocida.

Localidad: Frente a Cojímar, cerca de la Habana, Cuba.

Profundidad: 450 brazas.

Referencia: Descriptions of new species of recent unstalked Crinoids from the coasts of

Northeastern Asia. Proceedings United States National Museum, 33 (1561): 127-156.

\section{LITERATURA CITADA}

Abreu, M. 1990. Lista actualizada de los ofiuroideos cubanos. Poeyana, 389: 1-13.

Abreu, M. 1997. Los asteroideos (Echinodermata) del Archipiélago Cubano. Avicennia, 6-7: 65-72.

Abreu, M., F. A. Solís Marín y A. Laguarda-Figueras. 2000. Los equinoideos (Echinodermata: Echinoidea) del Archipiélago Cubano. Avicennia, 12-13: 69-78.

Abreu, M., F. A. Solís-Marín y A. Laguarda-Figueras. 2005. Catálogo de los equinodermos (Echinodermata: Asteroidea y Ophiuroidea) neríticos-bentónicos del Archipiélago Cubano. Revista de Biología Tropical, 53 (Supl.3): 29-52.

Agassiz, A. 1888. Characteristic deep-sea types. Echinoderms. Three cruises of the United States Coast and Geodetic Survey Steamer "Blake" in the Gulf of Mexico in the Caribbean Sea, and along the Atlantic Coast of theUnited States, from 1877 to 1880. The Riverside Press, Cambridge, 2: 84-127.

Baumiller, T. K. y C. G. Messing. 2007. Stalked crinoid locomotion, and its ecological and evolutionary implications. Palaeontologia Electronica 10(1) 2A:10 p, $12 \mathrm{MB}$. http://palaeo electronica.org/paleo/2007_1/crinoid/index.html.

Baumiller, T. K., R. Mooi y C. G. Messing. 2008. Urchins in the meadow: paleobiological and evolutionary implications of cidaroid predation on crinoids. Paleobiology, 34(1): 35-47.

Clark, A. H. 1907. Descriptions of new species of recent unstalked Crinoids from the coasts of Northeastern Asia. Proceedings United States National Museum, 33(1561): 127-156.

Clark, A. H. 1918. The unstalked crinoids of the Siboga Expedition, 42(b): 219-220.

Clark, A. H. 1931. A Monograph of the existing Crinoids.Volume 1: The Comatulids. Part. 3: Superfamily Comasterida. Bulletin of the United States National Museum, 82: 816 pp. 
Clark, A. H. 1936. Five new genera and two new species of unstalked crinoids. Proceedings of the United States National Museum, 83(2982): 245-250.

Clark, H. L. 1900. The echinoderms of Porto Rico. Bulletin of the United States Fish Commission. 20 (part 2): 231-263.

Clark, H. L. 1908. Descriptions of new species of recent unstalked Crinoids from the coasts of Northeastern Asia. Proceedings United States National Museum, 33(1561):155-156.

Clark, H. L. 1918. The unstalked crinoids of the Siboga Expedition, 42(b): 219-220.

Clark, H. L. 1933. A handbook of the littoral echinoderms of Porto Rico and the other West Indian Islands. Sci. Surv. Porto Rico \& Virgin Islands, 16: 1-147.

Clark, H. L. 1940. The family Antedonidae in the West Tropical Atlantic. Memorias de la Sociedad Cubana de Historia Natural "Felipe Poey", 14(2): 139-160.

Clark, H. L. 1941. Reports on the scientific results of the Atlantis Expeditions to the West Indies, under the joint auspices of the University of Havana and Harvard University. The Echinoderms (Other than Holothurians). Memorias de la Sociedad Cubana de Historia Natural "Felipe Poey", 15(1): 6-7.

Del Valle García, R., F. A. Solís-Marín, M. Abreu Pérez, A. Laguarda-Figueras y A. Durán- González. 2005. Catálogo de los equinodermos (Echinodermata: Crinoidea, Echinoidea, Holothuroidea) nerítico-bentónicos del Archipiélago Cubano. Revista de Biologia Tropical, 53 (Suppl. 3): 9-28.

Gervais, F. L. P. 1835. Encrines, in Guérin. Dictionnaire pittoresque d'histoire naturelle et des phénomènes de la nature, Lenormand (éd.), Paris 3: 48-49.

Hemery, L. G., M. Roux, N. Ameziane y M. Eleaume. 2013. High-resolution crinoid phyletic inter-relationships derived from molecular data. Cah. Biol. Mar., 54: 511-523.

Ibarzábal Bombalier, D., M. V. Orozco, E. Gutiérrez, R. Cortés, Y. Alfonso, N. Barbán, S. A. Gallardo, C. J. Alonso y A. Blanco. 2010. Multimedia “Corales Pétreos de Cuba”. Acuario Nacional de Cuba, Agencia de Medio Ambiente, CITMA. ISBN 978-959-300-007-9.

Messing, C. G. 2003. Unique morphology in the living bathyal feather star, Atelecrinus (Echinodermata: Crinoidea). Invertebrate Biology, 122(3): 280-292.

Messing, C. G. 2004. Biozonation on deep-water carbonate mounds and associated hardgrounds along the western margin of Little Bahama Bank, with notes on the Caicos Platform island slope. Pp. 107-115 IN Lewis, R. D. and Panuska, B. C. (eds.) $1^{\text {st }}$ Symposium on the Geology of the Bahamas and other Carbonate Regions, Gerace Research Center, San Salvador, Bahamas.

Messing, C. G. y J. D. Dearborn. 1990. Marine Flora and Fauna of the Northeastern United States. Echinodermata: Crinoidea. NOOA Technical Report MFS. 91: 30pp.

Messing, C. G., J. David, M. Roux, N. Améziane y T. K. Baumiller. 2007. In situ stalk growth rates in tropical western Atlantic sea lilies (Echinodermata: Crinoidea). J. Exp. Mar. Biol. Ecol., 353 (2): 211-220. 
Parra, A. 1787. Decripción de differentes piezas de historia natural las mas del ramo maritimo, representadas en setenta y cinco laminas, Cuba, $191 \mathrm{pp}$.

Pourtalès, L. F. de. 1868. Contributions to the Fauna of the Gulf Stream at great depths. Bulletin of the Museum of Comparative Zoology at Harvard College, 1 (6): 103-120.

Pourtalès, L. F. de, 1869. List of the Crinoids obtained on the Coasts of Florida and Cuba, by the United States Coast Survey Gulf Stream Expeditions, in 1867, 1868, 1869. Bulletin of the Museum of Comparative Zoology at Harvard College, 1 (11): 355-358.

Pourtalès, L.F. de. 1878. Crinoids. Report on the results of dredging, under the supervision of Alexander Agassiz in the Gulf of Mexico by the United States Coast Survey steamer "Blake". Bulletin of the Museum of Comparative Zoology at Harvard College, 5 (9): 214-216.

Rodríguez-Barreras, R. y C. G. Messing. 2013. A new list of Cuban crinoids (Echinodermata: Crinoidea). Caribbean Journal of Science, 47(2-3): 198-212.

Rouse, G. W., L. S. Jermiin, N. G. Wilson, I. Eeckhaut, D. Lanterbecq, T. Oji, C. M. Young, T. Browning, P. Cisternas, L.E. Helgen, M. Stuckey y C.G. Messing. 2013. Fixed, free, and fixed: the fickle phylogeny of extant Crinoidea (Echinodermata) and their Permian-Triassic origin. Mol. Phylogenet. Evol., 66 (1): 161-81.

Suárez, A. M. 1974. Lista de equinodermos cubanos recientes. Revista Investigaciones Marinas, 6: 61-72.

[Recibido: 16 de enero, 2016. Aceptado para publicación: 30 de septiembre, 2016] 